\title{
A Study on the Effect of Beauty Service of the Elderly on Successful Ageing: Focused on Mediated Effect of Self-esteem
}

\author{
Myung-Hee Jung ${ }^{1}$, Ji-Sun Moon ${ }^{2}$
}

Received : August 9, 2018 Revised: October 1, 2018 Accepted: October 10, 2018

\begin{abstract}
The interest in decrepitude expanded by graying is gradually growing in modern society. Moreover, he concern over decrepitude along with healthy mind and body is increasing. Therefore, there are many concerns and efforts toward physical and mental health. In addition, the interest in and effort for appearance health and value is rising as well as physical and mind health. The middle age is the most stable age based on the economic and social status that had been achieved through the life, but it is the most stressful age due to physical health problem and appearance ageing. There are many advanced studies for self-esteem and life satisfaction in old age by using hair, skin-care, cosmetic, nail-art among beauty related fields but studies on self-esteem and perception of successful ageing through user satisfaction of beauty service is lacking. This study is aiming to verify empirically the positive effect of self-esteem improvement through user satisfaction of beauty service on perception of successful ageing for middle-aged over 50 years old. The study has assumed that the higher middle-aged's satisfaction of beauty service is, the more self-esteem improves and there has a mediated effect to contribute successful ageing.
\end{abstract}

Keywords: Beauty Service, User Satisfaction, Perception of Successful Ageing.

JEL Classification Code: H75, I31, J15, R13.

\section{Introduction}

The interest in decrepitude expanded by graying is gradually growing in modern society. Moreover, he concern over decrepitude along with healthy mind and body is increasing. Therefore, there are many concerns and efforts toward physical and mental health. In addition, the interest in and effort for appearance health and value is rising as well as physical and mind health. The middle age is the most stable age based on the economic and social status that had been achieved through the life, but it is the most stressful age due to physical health problem and appearance aging.

According to the findings by Korea Institute for Health and Social Affairs in 2010 2012, the senile depression and

1 First Author. Professor, Department of Social Welfare, Jungwon University, Korea. E-mail: jmhsubject@hanmail.net.

2 Corresponding Author. Professor, Department of Beauty and Health, Jungwon University, Korea. Tel: +82-43-830-8865.

E-mail: mjs@jwu.ac.kr. satisfaction of decrepitude had been shown depends on the ability of preparation for Golden age, and when the target has low social status and education level, its satisfaction of its old age dropped. The advanced study about the effect of stress from appearance aging in old age on self-esteem and satisfaction of decrepitude showed that when the stress due to low confidence from appearance aging is high and when the self-esteem is low, the satisfaction of decrepitude drops and the perception of successful aging is declined.

Since human history started, the beauty desire had become the basic instinct and raw thing of humanity and it had been built in various aspects through the age. This beauty desire had developed cosmetic culture in various aspects and leaded to current cosmetic culture. Human being spares no expense in time and financial investment for appearance beauty. In this day, appearance image become more important than the image of character, personality, and basic attitude which are important in the past, and the image of position and success is changing through the appearance. Every gender is investing many time and costs for improvement of appearance to look 
younger. Beauty treatment is one of its own expressions to reduce daily stress and is a part of total beauty to express its own personality. Beauty management is an outward expression method to give confidence in interpersonal relations and to deliver good impression.

There are many advanced studies for self-esteem and life satisfaction in old age by using hair, skin-care, cosmetic, nail-art among beauty related fields but studies on selfesteem and perception of successful ageing through user satisfaction of beauty service is lacking.

This study is aiming to verify empirically the positive effect of self-esteem improvement through user satisfaction of beauty service on perception of successful ageing for middle-aged over 50 years old. The study has assumed that the higher middle-aged's satisfaction of beauty service is, the more self-esteem improves and there has a mediated effect to contribute successful ageing..

\section{Advanced Study Review}

\subsection{Influence Factor of Successful Ageing}

Successful ageing means a condition to adapt effectively by using resilience in response to physical change in old age and to achieve physical, mental, and social peace. A concept of successful ageing had emerged to change the perception toward the elderly and emphasizes the participation in social activity vigorously. Successful ageing could achieve even it has disease and earns less. Therefore, personal subjective awareness is reflected actively (Kim, 2013).

The elderly is considered that they are easy to experience the reduction of social relations and mental problems due to disease risk caused by aging and expansion of poverty risk by declining work capacity. The elderly used to be considered as to need care, but on the other, they used to be considered as lethargic, incompetent, and burdensome people (Jeong \& Seo, 2015).

However, many elderly could spend their time actively longer due to the development of medical technology and the establishment of welfare system for the elderly. Comparing with their young adults period, the reduction of physical ability is indisputable but their inner ability to deal with it is strengthening. Moreover, there is strong atmosphere to make a connection between this characteristic of elderly and a concept of 'successful ageing' (Choi, 2013; Song, 2018). There is a conversion of viewpoint that the elderly is a subject of problem solution to achieve happy old age instead of considering it as a cause of the problem in the viewpoint of lifespan (Choi, Back, \&
Seo, 2005; Back, 2008; Lee \& Ahn, 2010). In this process, the interest in successful ageing has been rapidly increased.

The representative scholars to establish the components of successful ageing are Rowe and Kahn (1998). They had divided into three components by stages; freedom from disability by illness, achievement of high level of physical mental ability, and active social participation. In addition, they had stressed on active social participation strongly. Freedom from disability by illness and achievement of high level of physical-mental ability had been accepted its importance as preconditions to make active social participation possible.

The model of successful ageing by Rowe abd Kahn had been supported by various advanced studies (Seong \& Cho, 2006; Kim, 2008; Kim \& Kim, 2009). First of all, physical ability, overall mental condition, health related behavior such as exercise smoking drinking, and subjective health recognition have a significantly effect on successful ageing. When the elderly is in good health, exercises regularly, and controls smoking and drinking, there is high probability of successful ageing (Kim \& Jeong, 2006; Kim \& Jeong, 2013). In addition, self-esteem, melancholy, and cognitive function has significantly effect on successful ageing. When selfesteem is high, melancholy is low, and cognitive function is activated, the possibility of successful ageing has risen (Chung, 2007). Finally, it is reported that various economic and leisure activity participation has an important effect on successful ageing. The elderly who participate in paid works, volunteer activities, club activities, and self-management activities briskly showed a high probability of successful ageing(Kim \& Kim, 2011; Kim, Lee, \& Yoon, 2013; Choi \& Kim, 2013). These results of advanced studies showed that the model of successful ageing by Rowe \& Kahn is suitable to Korean situation universally.

The important thing is that the factors to influence in successful ageing are closely bound up with each other instead of being divided into separate areas. The active participation of social activity is a source of high self-esteem (Kim \& Lee, 2011; Kim, 2012; Lee \& Hong, 2012), and high self-esteem acts as a drive factor to significantly influence in successful ageing achievement (Jeong, 2018). It showed that it is necessary to analyze the mediated effect of influence of each factor in successful ageing.

\subsection{Relation Between Self-esteem and Successful Ageing}

Rosenberg (1965) who invented the index of self-esteem had defined self-esteem as 'the degree to evaluate and respect oneself valuably'. In a similar vein, many studies has defined self-esteem as a perception of one's value and 
importance created through evaluation of self-image and recognition of identity(Harter, 1999; Chung, 2004).

Maslow (1970) had classified human's five desires as physiological needs, desire for security, desire for belonging and love, desire for esteem, and desire for self-realization. Self-esteem falls under desire for esteem and it is seriously affected by meeting desire for belonging and love.

Self-esteem has a significant implication specially for the elderly. The elderly's self-esteem is a factor to maintain good mental health and improve the quality of life (Jin, 2010). The elderly who has high self-esteem shows to have positive self-concept and self-control ability as well as confidence to protect from others (Kim \& Kim, 2002). The higher the self-esteem of the elderly is, the easier it is to adopt physical and role change (Chung, 2004). These study results suggested that the elderly's self-esteem might have a significantly effect on successful ageing. When the elderly has high self-esteem, their possibility to achieve successful ageing is high practically (Jeong, 2018).

Whereas, the elderly's self-esteem has been influenced by goal attainment which is considered to have an important meaning (Coopersmith, 1967). When the elderly set and achieve their own goal, their self-esteem increases. It means that self-esteem has been affected by interrelation instead of determining by inherent character (Lee \& Hong, 2012). For example, the self-esteem of elderly who lives in facility is lower than others who does not live in facility because it is hard to receive the respect for own values through interrelation between family and friends within limited space (Chung, 2004). In other word, the self-esteem of elderly seems to be secured when desire for belonging and love by Maslow (1970) had been recognized (Krause, 1987).

In this respect, it has reported that beauty service use has significantly effect on the improvement of self-esteem (Lee, Lee, \& Kim, 2009; Koh, Jang, \& Ahn, 2012). The beauty service use itself could be a friendship activity to revitalize interrelation, contribute to reduce discrimination and ignorance due to skin and beauty problems, and make easy to have social activity and goal achievement. Therefore, it has been evaluated to contribute the achievement of desire for belonging and love (Oh, Jeong, \& Choi, 2010).

\subsection{Relation Among Beauty Service Use, Self- esteem, and Successful Ageing}

It is reported that satisfying beauty service use has positive effect on self-esteem and stress reducing for female (Back \& Jang, 2012). A study conducting an analysis targeting the elderly is suggesting similar conclusion. When the elderly's user satisfaction of beauty service is high, their self-esteem is high and their melancholy is low (Oh,
Jeong, \& Choi, 2010). High self-esteem had considered to increase the possibility of successful ageing and it is considered that satisfying beauty service use could have positive effect on successful ageing.

It is possible to explain by activity theory that beauty service use has significantly effect on self-esteem and successful ageing. Activity theory considers that when the elderly is enjoying active social life, their happiness increases (Hendricks, 1992). Although the elderly has inevitable physical change, they maintains psychosocial desire which is similar with middle-aged class. The elderly gain mental satisfaction when their middle-aged activities are maintaining and their desires are satisfied. That means, when role loss is reducing by active social activities, positive self-concept could be gained because it is easy to receive social support from others (Lemon, Bengtson, \& Peterson, 1972).

It is time to reduce that the middle-aged is reducing their economic activity. Therefore, their financial ability and relation range is reducing. However, when alternative social activities are maintained and friendships are achieving, they could recover role loss (Havinghurst, 1973). The middleaged gain their satisfaction through home, community, religious and social group, family, relatives, friends, and neighbors (Kim, 2008). Social activity is every social action that a doer imparts a meaning and confirms same quality based on the similar lifestyle, experience, and sharing value. Every significantly and purposeful interpersonal activity is included social activity (Song, 2018).

Every social activity in old age could be a productive activity in a broad category. Paid work, domestic chores, household affairs, volunteer work, leisure activity, and appearance and health care could be included in the productive activity because these activities create economic, physical, mental, and social value respectively(Kim \& Kim, 2009). The elderly's productive activity including appearance and health care has positive effect on successful ageing because it makes the elderly not to consider their aging gloomily (Kaufman, 1986). The leisure life and hobby activity of the elderly in Korea has more important effect on successful ageing than paid work (Hong, 2005).

The beauty service use could contribute to achieve successful ageing as part of social-productive activity in a broad sense. The achievement of beauty purpose by beauty service use contributes mental self-achievement and selfexpression and help to reduce sense of crisis in climacterium and melancholy in old age. Eventually, the realization of aesthetic value is playing an important role to improve life quality and achieve successful ageing (Kim, Lee, \& Yoon, 2013). 
As above advanced studies show, it is expected that there is a significantly mediated effect among beauty service use, self-esteem, and successful ageing of the middle-aged. In a concrete way, it could suppose that when user satisfaction of beauty service is high, the self-esteem of middle-aged is improving, and when self-esteem is improving, perception of successful ageing would be improved.

\section{Research Methods}

\subsection{Research Material}

This study conducted a survey of middle-aged over 50 years old who have experience a beauty service. The survey period was from April to June in 2018, and the targets who had an experience to use beauty facilities had been received questionnaire on a national scale. Total 400 questionnaires had been distributed and 95 answers had been eliminated due to their missing value. 305 answers had been coded and analyzed.

\subsection{Research Tool}

\subsubsection{Independent Variable}

The independent variable of this study is user satisfaction of beauty service. The user satisfaction of beauty service had been composed by modifying evaluation index of user satisfaction of social welfare service by Kim et al. (2007). This study had analyzed the social welfare aspect of beauty service such as successful ageing and self-esteem. Therefore, it had been appropriated to adopt user satisfaction of social welfare service. The scale consists of 13 sub-questions measured by the 5-point Likert scale, and the larger the value is, the stronger the agreement is with the question. The user satisfaction of beauty service is summarized in the $\langle$ Table 1$\rangle$.

\subsubsection{Parameter}

The parameter of this study is self-esteem. The index of self-esteem had been applied by questions of Rosenberg Self-Esteem Scale. Rosenberg Self-Esteem Scale consists of 6 sub-questions and every question contains positive question. The index of self-esteem's sub-questions had been measured by the 5-point Likert scale, and the larger the value is, the stronger the agreement is with the question.

Table 1: Index of user satisfaction of beauty service

\begin{tabular}{|l|l|}
\hline \multicolumn{1}{|c|}{ category } & \multicolumn{1}{|c|}{ content } \\
\hline \multirow{4}{*}{$\begin{array}{l}\text { user satisfaction of } \\
\text { beauty service }\end{array}$} & The beauty services I received here are very helpful to me. \\
\cline { 2 - 2 } & The staff here seem to be really helping me out. \\
\cline { 2 - 2 } & If beauty services are needed again, I will be reused. \\
\cline { 2 - 3 } & The staff treat me as respectfully instead of treating me commercially. \\
\cline { 2 - 3 } & I learned a lot about how to deal with my beauty problems. \\
\cline { 2 - 3 } & The staff are doing their job well. \\
\hline & I have received the service that I really need from here. \\
\cline { 2 - 3 } & The staff accept me the way I am. \\
\hline & My beauty condition is much better now than when I first came here. \\
\cline { 2 - 3 } & The service I received here is worth the price I paid. \\
\cline { 2 - 3 } & The staff do the work what I request preferentially. \\
\cline { 2 - 3 } & The people who know me told that I have been positively changed after I received beauty service. \\
\hline
\end{tabular}

Table 2: Index of self-esteem

\begin{tabular}{|l|l|}
\hline \multicolumn{1}{|c|}{ category } & \\
\hline \multirow{4}{*}{ self-esteem } & I think I am a valuable person like everyone else. \\
\cline { 2 - 2 } & I think I have good nature. \\
\cline { 2 - 2 } & I can work well like everyone else. \\
\cline { 2 - 2 } & I have a positive attitude for myself. \\
\cline { 2 - 2 } & I am generally satisfied with myself. \\
\cline { 2 - 2 } & I wish I respect myself more. \\
\hline
\end{tabular}




\subsubsection{Dependent Variable}

The dependent variable of this study is perception of successful ageing. The index by Ahn, Kang, and Kim (2009) which had been applied as a standard of leading study for middle-aged's successful ageing criterion had been injected for the perception of successful ageing. The index consists of three dimensions: daily stability, psychological and social stability, and self-efficacy, and 18 sub-questions. The sub questions had been measured by the 5-point Likert scale, and the larger the value is, the stronger the agreement is with the question. The sub-questions of perception of successful ageing index is summarized in the <Table $3>$.

\subsubsection{Control Variable}

The control variable of this study consists of income level, education level, economic activity state, housing type, gender, age, marriage, and health condition and they are mentioned as important influencing factors of perception of successful ageing. The income level is measured through the question with the unit of total house income as one million won. This study defined that the low income group is that its total house income is less than 2 million won per monthly average, the middle income group is between more than 2 million won and less than 5 million won per monthly average, and the high income group is more than 5 million won per monthly average, and they had been analyzed. Considering the characteristic of middle-aged, the education level had been divided into less than middle school, high school, and over college. The economic activity state had been divided by paid work participation. The housing type had been divided into owned, rent, monthly rent, and living in children's house. The age had been categorized middleaged which is between over 50 years old and less 64 years old, and old-aged which is over 65 years old. The marriage had been divided into married-having spouse divorce-bereavement-separation. The health condition had been measured by 5-point Likert scale, and the larger the value is, the healthier its condition is. This analysis framework is summarized in the $\langle$ Table $4>$.

Table 3: Index of perception of successful ageing

\begin{tabular}{|c|c|}
\hline category & content \\
\hline \multirow{5}{*}{ daily stability } & I can spend time well. \\
\hline & I am well-prepared for the economy. \\
\hline & I am comfortable to move my body. \\
\hline & I feel at ease. \\
\hline & I am easy to engage with others well. \\
\hline \multirow{8}{*}{$\begin{array}{l}\text { psychological } \\
\text { and social } \\
\text { stability }\end{array}$} & I am interested in helping others. \\
\hline & I can get necessary service and resource. \\
\hline & I interact with others regularly. \\
\hline & I participate in various activities. \\
\hline & I could contribute something to society. \\
\hline & I could be able to adapt to change. \\
\hline & I thank for my achievements through my life. \\
\hline & I can be satisfied my life. \\
\hline \multirow{5}{*}{ self-efficacy } & $\begin{array}{l}\text { I could maintain excellent thinking ability and } \\
\text { memory. }\end{array}$ \\
\hline & I have abilities to develop myself. \\
\hline & I can do what I want to achieve. \\
\hline & I manage my life thoroughly. \\
\hline & $\begin{array}{l}\text { I could deal with daily problems and challenges } \\
\text { effectively. }\end{array}$ \\
\hline
\end{tabular}

Table 4: Analysis framework

\begin{tabular}{|c|c|c|}
\hline Sort & variable identifier & definition and measurement of variable \\
\hline dependent variable & perception of successful ageing & continuous variable (minimum $=0$, maximum $=100$ ) \\
\hline independent variable & user satisfaction of beauty service & continuous variable (minimum $=0$, maximum $=100$ ) \\
\hline parameter & self-esteem & continuous variable (minimum $=0$, maximum $=100$ ) \\
\hline \multirow{8}{*}{ control variable } & income level & low income $=0$, middle income $=1$. high income $=2$ \\
\hline & education level & less middle school=0, high school=1, over college $=2$ \\
\hline & economic activity state & participate in paid work=0, not participate in paid work=1 \\
\hline & housing type & owned $=0$, rent $=1$, monthly rent $=2$, living in children's house $=3$ \\
\hline & gender & male $=0$, female $=1$ \\
\hline & age & over $50 \sim$ less $64=0$, over $65=1$ \\
\hline & marriage & married $\cdot$ having spouse $=0$, divorce $\cdot$ bereavement $\cdot$ separation $=1$ \\
\hline & health condition & continuous variable (minimum $=0$, maximum $=4$ ) \\
\hline
\end{tabular}




\subsection{Analysis Method}

This study is aiming to investigate general characteristic of sample through descriptive statistics and verify the reliability and validity of perception of successful ageing, user satisfaction of beauty service, self-esteem index through reliability analysis and exploratory factor analysis. Finally, multiple regression analysis and Sobel-Test would be conducted between independent variable-parameter, and independent variable-dependent variable for verification whether mediated effect of self-esteem is significantly different when user satisfaction of beauty service has an effect on perception of successful ageing. SPSS for Windows 24.0 package had been used for above analyses.

\section{Analysis Result}

\subsection{General Characteristic of Sample}

The sociodemographic characteristics of sample for analysis of actual proof had been summarized in the $<$ Table 5>. Total respondents were 305 and every had experienced beauty service use.

193 respondents are over 65 years old and they were $63.3 \%$ of total as well as the most frequent group. 112 respondents are between over 50 years old and less 64 years old, which were $36.7 \%$ of total. The education level showed that 155 respondents had chosen over college which was the largest $(50.8 \%)$, and 85 respondents had chosen high school which is $27.9 \%$, less than middle school was 65 respondents, which was $21.3 \%$. The income level showed that the middle-income group was 142 respondents which was $46.6 \%$, the highest frequent group. The highincome group was 98 respondents which was $32.1 \%$, the low-income group was 65 respondents which was $21.3 \%$. The economic activity level showed that 185 respondents which was $60.7 \%$ had responded that they do not have paid work, and 120 respondents as $39.3 \%$ said that they participate in paid work. Marriage showed that $77.7 \%$ as 237 respondents were married, having spouse, and $22.3 \%$ as 68 respondents were divorce, bereavement, and separation. The health condition showed that 98 respondents as $32.1 \%$ had responded very good, 86 respondents as $28.2 \%$ had responded good, and 11 respondents as $3.6 \%$ had responded very bad. The housing type showed that 112 respondents as $36.7 \%$ had chosen 'rent', 96 respondents as $31.5 \%$ had chosen 'owned', 52 respondents as $17.0 \%$ had chosen 'living in children's house', and 45 respondents as $14.8 \%$ had chosen 'monthly rent'.
Table 5: Sociodemographic characteristics of study targets

\begin{tabular}{|c|c|c|c|}
\hline \multicolumn{2}{|r|}{ sort } & frequency & percent \\
\hline \multirow{2}{*}{ gender } & male & 93 & 30.5 \\
\hline & female & 212 & 69.5 \\
\hline \multirow{2}{*}{ age } & over $50 \sim$ less 64 & 112 & 36.7 \\
\hline & over 65 & 193 & 63.3 \\
\hline \multirow{3}{*}{$\begin{array}{l}\text { education } \\
\text { level }\end{array}$} & less middle school & 65 & 21.3 \\
\hline & high school & 85 & 27.9 \\
\hline & over college & 155 & 50.8 \\
\hline \multirow{3}{*}{$\begin{array}{l}\text { income } \\
\text { level }\end{array}$} & low income & 65 & 21.3 \\
\hline & middle income & 142 & 46.6 \\
\hline & high income & 98 & 32.1 \\
\hline \multirow{2}{*}{$\begin{array}{l}\text { economic } \\
\text { activity level }\end{array}$} & participate in paid work & 120 & 39.3 \\
\hline & not participate in paid work & 185 & 60.7 \\
\hline \multirow[b]{2}{*}{ marriage } & married, having spouse & 237 & 77.7 \\
\hline & $\begin{array}{c}\text { divorce, bereavement, } \\
\text { separation }\end{array}$ & 68 & 22.3 \\
\hline \multirow{5}{*}{$\begin{array}{c}\text { health } \\
\text { condition }\end{array}$} & very bad & 11 & 3.6 \\
\hline & bad & 26 & 8.5 \\
\hline & normal & 86 & 28.2 \\
\hline & generally good & 84 & 27.5 \\
\hline & good & 98 & 32.1 \\
\hline \multirow{4}{*}{$\begin{array}{l}\text { housing } \\
\text { type }\end{array}$} & owned & 96 & 31.5 \\
\hline & rent & 112 & 36.7 \\
\hline & monthly rent & 45 & 14.8 \\
\hline & living in children's house & 52 & 17.0 \\
\hline
\end{tabular}

\subsection{Result of Reliability Analysis and Exploratory Factor Analysis}

The result of exploratory factor analysis about perception of successful ageing had been suggested in <Table 6>.

The eigen value of factor analysis result showed that psychological and social stability is 7.03 , daily stability is 3.76 , self-efficacy is 2.88 , and variance explanation power is $71.97 \%$. KMO figure was .919 which had considered that variable selection for factor analysis is appropriate. Therefore, it assumes that the validity of measurement tool had been thoroughly verified. According to the verification of Barlett's Test result to show model's suitability, significance probability was $p<.001$ which is statistically significant. In addition, to verify internal consistency, Cronbach's a had been conducted and it showed that psychological and social stability is .954 , daily stability is .903 , and self-efficacy is .842 , and these had been revealed the measure reliability. 
Table 6: exploratory factor analysis of perception of successful ageing

\begin{tabular}{|c|c|c|c|c|}
\hline question & psychological and social stability & daily stability & self-efficacy & C'sa \\
\hline perception of successful ageing7 & .879 & .126 & .061 & \multirow{8}{*}{.954} \\
\hline perception of successful ageing8 & .876 & .091 & .147 & \\
\hline perception of successful ageing10 & .874 & .068 & .140 & \\
\hline perception of successful ageing11 & .864 & .019 & .156 & \\
\hline perception of successful ageing 6 & .850 & .164 & .071 & \\
\hline perception of successful ageing13 & .840 & .182 & .176 & \\
\hline perception of successful ageing12 & .838 & .161 & .185 & \\
\hline perception of successful ageing 9 & .826 & .172 & .105 & \\
\hline perception of successful ageing3 & .082 & .869 & .139 & \multirow{5}{*}{.903} \\
\hline perception of successful ageing 4 & .079 & .828 & .191 & \\
\hline perception of successful ageing2 & .143 & .819 & .223 & \\
\hline perception of successful ageing 5 & .153 & .796 & .184 & \\
\hline perception of successful ageing 1 & .167 & .790 & .134 & \\
\hline perception of successful ageing18 & .197 & .241 & .797 & \multirow{5}{*}{.842} \\
\hline perception of successful ageing17 & .285 & .094 & .772 & \\
\hline perception of successful ageing14 & .190 & .260 & .753 & \\
\hline perception of successful ageing 15 & .061 & .302 & .735 & \\
\hline perception of successful ageing16 & .048 & .265 & .711 & \\
\hline Eigen values & 7.03 & 3.76 & 2.88 & \\
\hline variance & 37.01 & 56.81 & 71.97 & \\
\hline
\end{tabular}

Table 7: Correlation analysis among major variables

\begin{tabular}{|c|c|c|c|c|c|c|}
\hline & & user satisfaction & self-esteem & inder & $x$ of perception of successful agei & \\
\hline & & of beauty service & sentesteem & daily stability & psychological and social stability & self-efficacy \\
\hline user satisfact & $\mathrm{n}$ of beauty service & 1 & & & & \\
\hline & -esteem & $.479^{* * *}$ & 1 & & & \\
\hline index of & daily stability & $.312^{* \star *}$ & $.436^{\star * *}$ & & & \\
\hline $\begin{array}{l}\text { perception of } \\
\text { successful }\end{array}$ & $\begin{array}{l}\text { psychological and } \\
\text { social stability }\end{array}$ & $.474^{* * *}$ & $.286^{* *}$ & .064 & 1 & \\
\hline ageing & self-efficacy & $.414^{\star *}$ & $.339 * *$ & $.180^{* *}$ & $.729^{* *}$ & 1 \\
\hline
\end{tabular}

${ }^{*} p<.05,{ }^{* *} p<.01,{ }^{* * *} p<.001$.

\subsection{Result of Correlation Analysis}

The results of interrelation between factors are in $<$ Table $7>$. The analysis results are as follows.

The user satisfaction of beauty service has significantly positive correlation with self-esteem $(r=.479, p<.001)$. It means the higher the user satisfaction of beauty service is, the higher the self-esteem is.

The user satisfaction of beauty service has significantly positive correlation with daily stability $(r=.312, p<.001)$, psychological and social stability $(r=.474, p<.001)$, and selfefficacy $(r=.414, p<.01)$ among perception of successful ageing. It means the higher the user satisfaction of beauty service is, the higher these three sub-domains in perception of successful ageing are.

The self-esteem has significantly positive correlation with daily stability $(r=.436, p<.001)$, psychological and social stability $(r=.286, p<.01)$, and self-efficacy $(r=.339, p<.01)$ among perception of successful ageing. It means the higher the self-esteem is, the higher these three sub-domains in perception of successful ageing are.

The daily stability has significantly positive correlation with self-efficacy $(r=.180, p<.01)$. It means the higher the daily stability is, the higher the self-efficacy is. 
The psychological and social stability has significantly positive correlation with self-efficacy $(r=.729, p<.01)$. It means the higher the psychological and social stability, the higher the self-efficacy is.

\subsection{Result of Mediated Effect Analysis}

Parameter influences a dependent variable like an independent variable and its order is between independent variable and dependent variable. It is affected by an independent variable as well as influencing on a dependent variable. Many mediational analysis use mediation regression analysis recently.

Baron and Kenny (1981) had introduced the method of causal steps approach to the study of mediated effect. This study is verifying the mediational analysis based on the causal steps approach by Baron and Kenny (1981). This study contains the analysis to consider self-esteem working as a mediated effect in the study of effect of user satisfaction of beauty service on perception of successful ageing.

Table 8: Hierarchical analysis verification result of perception of successful ageing

\begin{tabular}{|c|c|c|c|c|c|c|c|c|c|}
\hline \multirow{2}{*}{\multicolumn{2}{|c|}{ model }} & \multicolumn{2}{|c|}{ nonstandard coefficients } & \multirow{2}{*}{$\begin{array}{c}\begin{array}{c}\text { standardized } \\
\text { coefficient }\end{array} \\
\text { beta }\end{array}$} & \multirow{2}{*}{$\mathbf{t}$} & \multirow{2}{*}{$\begin{array}{c}\text { significance } \\
\text { probability }\end{array}$} & \multicolumn{2}{|c|}{ colinearity statistics } & \multirow{2}{*}{$\mathbf{R}^{2}$} \\
\hline & & B & standard error & & & & tolerance & VIF & \\
\hline \multirow[b]{2}{*}{1} & (constant) & 1.054 & .220 & & 4.784 & .000 & & & \multirow[b]{2}{*}{.265} \\
\hline & $\begin{array}{l}\text { user satisfaction of beauty } \\
\text { service }\end{array}$ & .148 & .083 & .116 & 1.769 & .000 & 680 & 1.471 & \\
\hline \multirow{3}{*}{2} & (constant) & 1.167 & .337 & & 3.459 & .001 & & & \multirow{3}{*}{.269} \\
\hline & $\begin{array}{l}\text { user satisfaction of beauty } \\
\text { service }\end{array}$ & .088 & .066 & .067 & 1.341 & .008 & 627 & 1.595 & \\
\hline & self-esteem & .513 & .054 & .468 & 9.563 & .000 & 659 & 1.517 & \\
\hline
\end{tabular}

Table 9: Procedure for mediation regression analysis

\begin{tabular}{|c|l|}
\hline stage & \multicolumn{1}{c|}{ content } \\
\hline stage 1 & $\begin{array}{l}\text { It should analyze significant influencing relationship of independent variable in parameter and influencing relationship } \\
\text { between two variables through regression analysis, and be significant influencing relationship under statistical significance } \\
\text { level. }\end{array}$ \\
\hline stage 2 & $\begin{array}{l}\text { It should analyze influencing relationship between independent and dependent variable through regression analysis, and } \\
\text { significantly influencing relationship of independent variable in dependent variable, and have influencing relationship under } \\
\text { statistical significance level. }\end{array}$ \\
\hline stage 3 3 & $\begin{array}{l}\text { It should analyze effects between variables through regression analysis, and significant influencing relationship of } \\
\text { independent and parameter in dependent variable, and be significant influencing relationship under statistical significance } \\
\text { level. }\end{array}$ \\
\hline stage 4 & $\begin{array}{l}\text { Confirm mediating relation through Sobel-Test formular and Sobel-Test value between stage 1 and stage 3(parameter) and } \\
\text { confirm significant value. }\end{array}$ \\
\hline
\end{tabular}

Table 10: Self-esteem mediational analysis of perception of successful ageing

\begin{tabular}{|c|c|c|c|c|c|c|}
\hline $\begin{array}{c}\text { independent } \rightarrow \text { parameter } \rightarrow \\
\text { dependent variable }\end{array}$ & mediated effect verification & $\begin{array}{c}\text { nonstandardized } \\
\text { beta value }\end{array}$ & $\begin{array}{l}\text { standard } \\
\text { deviation }\end{array}$ & $\mathrm{t}$ values & p values & $\mathbf{R}^{2}$ \\
\hline \multirow{4}{*}{$\begin{array}{c}\text { user satisfaction of beauty service } \rightarrow \\
\text { self-esteem } \rightarrow \text { daily stability }\end{array}$} & stage 1 (independent $\rightarrow$ parameter) & .424 & .043 & 9.839 & .000 & .171 \\
\hline & stage2(independent $\rightarrow$ dependent) & .547 & .048 & 11.368 & .000 & .216 \\
\hline & stage3(independent variable ) & .441 & .052 & 8.549 & .000 & .256 \\
\hline & stage3( parameter) & .250 & .050 & 4.970 & .000 & .256 \\
\hline \multirow{4}{*}{$\begin{array}{c}\text { user satisfaction of beauty service } \rightarrow \\
\text { self-esteem } \rightarrow \text { psychological and } \\
\text { social stability }\end{array}$} & stage 1 (independent $\rightarrow$ parameter) & .351 & .053 & 6.678 & .000 & .087 \\
\hline & stage2(independent $\rightarrow$ dependent) & .547 & .048 & 11.368 & .000 & .216 \\
\hline & stage3(independent variable) & .499 & .050 & 10.010 & .000 & .234 \\
\hline & stage3(parameter) & .137 & .042 & 3.271 & .001 & .234 \\
\hline \multirow{4}{*}{$\begin{array}{c}\text { user satisfaction of beauty service } \rightarrow \\
\text { self-esteem } \rightarrow \text { self-efficacy }\end{array}$} & stage 1 (independent $\rightarrow$ parameter) & .266 & .041 & 6.449 & .000 & .082 \\
\hline & stage2(independent $\rightarrow$ dependent) & .590 & .037 & 16.132 & .000 & .357 \\
\hline & stage3(independent variable ) & .555 & .038 & 14.694 & .000 & .371 \\
\hline & stage3(parameter) & .130 & .040 & 3.219 & .001 & .371 \\
\hline
\end{tabular}


The regression analysis showed that the mediated effect of self-esteem is significantly in the effect of beauty service satisfaction on successful ageing. The parameter of dependent variable in daily stability was the highest. <Table $11>$ showed that when Sobel test statistic ( $Z$ value) is bigger than 1.96 or smaller than -1.96 , it might be considered as mediated effect had been worked. In addition, every Twotailed probability ( $P$ value) shows significant in $p<0.01$.

Table 11: Sobel Test about parameter of self-esteem

\begin{tabular}{|c|c|c|}
\hline $\begin{array}{c}\text { independent } \rightarrow \text { parameter } \rightarrow \\
\text { dependent variable }\end{array}$ & $\begin{array}{c}\text { Sobel test } \\
\text { statistic } \\
\text { (z vallues) }\end{array}$ & $\begin{array}{c}\text { Two-tailed } \\
\text { probability } \\
\text { (P values) }\end{array}$ \\
\hline $\begin{array}{c}\text { user satisfaction of beauty service } \\
\rightarrow \text { self-esteem } \rightarrow \text { daily stability }\end{array}$ & 4.459 & 0.000 \\
\hline $\begin{array}{c}\text { user satisfaction of beauty service } \\
\rightarrow \text { self-esteem } \rightarrow \text { psychological } \\
\text { and social stability }\end{array}$ & 2.926 & 0.003 \\
\hline $\begin{array}{c}\text { user satisfaction of beauty service } \\
\rightarrow \text { self-esteem } \rightarrow \text { self-efficacy }\end{array}$ & 2.906 & 0.004 \\
\hline
\end{tabular}

\section{Conclusions}

This study had aimed to verify empirically the positive influencing effect of perception of successful ageing by improving self-esteem through user satisfaction of beauty service of middle-aged who is over 50 years old. The results are as follows.

First, the perception of successful ageing seems to be classified into three(daily stability, psychological and social stability, self-efficacy). This study had defined and classified the perception of successful ageing into three sections.

Second, correlation analysis among each variable showed that they have positive correlation with each other. In other word, when the user satisfaction of beauty service is increasing, the self-esteem is improving and the perception of successful ageing is improving.

In the corelation with user satisfaction of beauty service, the positive correlation with psychological and social stability is the highest and the relation with self-esteem also shows high $\mathrm{p}>$.001).

Third, the user satisfaction of beauty service and the selfesteem had positive effect on the perception of successful ageing. When the beauty satisfaction is increasing, daily stability, psychological and social stability, and self-efficacy which are sub-variables of perception of successful ageing are increasing.

Fourth, it had been proved a hypothesis that self-esteem might be work as a mediated effect in influencing relationship between user satisfaction of beauty service and perception of successful ageing. First of all, it had been verified that self-esteem had mediated effect in influencing relation between user satisfaction of beauty service and daily stability as sub-variable of perception of successful ageing. When the user satisfaction of beauty service is increasing, the self-esteem is increasing which means that daily stability as sub-variable of perception of successful ageing is also increasing $(p>.001, Z=4.459)$. In mediated effect of self-esteem, the influencing relation for ser satisfaction of beauty service and daily stability were the highest.

When the user satisfaction of beauty service is increasing, the self-esteem is increasing. This result had lead that the psychological and social stability which is sub--variable of perception of successful ageing is also increasing $(p>.001$, $\mathrm{Z}=2.926)$,

When the user satisfaction of beauty service is increasing, the self-esteem is increasing. This result had lead that the self-efficacy which is sub--variable of perception of successful ageing is also increasing( $p>.001, Z=2.906)$,

As a result, it is assumed that the support or management for external beauty such as internal health or mental stability is needed in the future. It is analyzed that beauty service contains mental stability effect for successful decrepitude and confidence improvement instead of changing external management, pursuing beauty trend simply. Therefore, this study suggests about beauty management based on the study result.

The study on beauty service had been conducted as other aspect of old stage program, and it is necessary to develop beauty support program for the elderly to give mental stability by offering regular service.

\section{References}

Back, M. R., \& Chang, C. G. (2012). The Effect of Nail and Hair Treatment on Stress and Self-esteem of Female. Korean public health research, 38(2), 109-115.

Choi, H. K. (2013). The Levels of Community-Residing Elderly"s Successful Aging and Their Predictors: Focusing on Korean Concept of Successful Aging. Journal of Institute for Social Sciences, 24(1), 193-217.

Choi, H. K., Paik, J. E., \& Seo, S. Y. (2005). The Perception of Successful Aging among Korean Elderly. Korean Home Management Association, 23(2), 1-10.

Choi, Y. S., \& Kim, Y. H. (2013). Effects of the Visual and Tactual Beauty Care Programs on Psychological Wellbeing of the Elderly Women at the Welfare Center. Journal of Investigative Cosmetology, 9(3), 279-287. 
Chung, S. D. (2004). Predictors of Self-Esteem Among Older Adults in Nursing Home. Korea Gerontological Society, 24(4), 107-122.

Chung, S. D. (2007). A Comparative Study on the Successful Aging for Korean Elderly Women and Elderly Men. Korea Gerontological Society, 27(4), 829-845.

Coopersmith, S. (1967). The Antecedents of Self-Esteem. San Francisco, CA: W.H. Freemanand Co. (1981, Reprint Edition).

Harter, S. (1999). The construction of the self. A developmental perspective. New York, NY: Guilford Press.

Havighurst, R. J. (1973). Developmental Tasks and Education (3rd ed.). New York, NY: D. Mckay Co.

Hendricks, J. (1992). Generations and the Generation of Theory in Social Gerontology, The International Journal of Aging and Human Development, 35(1), 31-47.

Hong, H. B. (2005). The Relationship Between Productive Activities and Successful Aging Among the aged. International Journal of Gerontological Social welfare, 29, 203-235.

Jeong, H. I. (2018). The Structural Relationship Between the Middle Aged Office Employees' Physical Cognitive, Psychological, and Social Factors and Successful Aging. Korea Gerontological Society, 38(1), 27-45.

Jin, Y. J. (2010). The Self-esteem of the Elderly and Relative Influence of Variables. Korean Family Resource Management Association, 14(4), 263-277.

Jung, Y. T., \& Suh, Y. S. (2015). The Development and Validation of a Scale to Measure Subjective Fairness: Caring for Aging Parents. International Journal of Gerontological Social welfare, 67, 277-298.

Kaufman S. R. (1986). The Ageless Self. Madison, WI: University of Wisconsin Press.

Kim, D. G., \& Jung, J. S. (2013). Relationship among Daily Stress, Perceived Health and Successful Aging of Older People Participating in Physical Activity. Journal of Sport and Leisure Studies, 54(1), 913-924.

Kim, J. H. (2012). The effects of youth volunteering on community consciousness and Life satisfaction mediated by self-esteem and ego-resilience. Journal of Youth Welfare, 14(1), 41-62.

Kim, K. H., \& Kim, J. H. (2009). A Structural Analysis of Successful Aging Factors for Korean Elderly. Korea Gerontological Society, 29(1), 71-87.

Kim, K. Y., \& Jung, Y. J. (2006). The Study on Elements of Successful Aging by Physical Health and Economic Status., International Journal of Gerontological Social welfare, 34, 31-54.

Kim, M. R. (2008). Factors of Successful Aging Affecting the Life Satisfaction of Older Women. Korea Gerontological Society, 28(1), 33-48.
Kim, S. H., \& Kim, Y. J. (2011). The Relationship Between Elderly Leisure Activity Participation and Recognition of Successful Aging. Journal of family relations, 15(4), 3-23.

Kim, S. H, \& Lee, C. E. (2011). A Study on Self-Efficacy and Self-Esteem of The Students Department of Cosmetology. Journal of The Korean Society of cosmetology, 17(6), 1138-1149.

Kim, S. K., Lee, J. E., \& Youn, M. K. (2013). Influencing Factors on Successful Aging of Middle-aged Women from an Aesthetic Point of View. Journal of academia-industrial technology, 14(8), 3682 - 3690.

Kim, Y. H., \& Kim, K. S. (2002). A Study on the Relationship between Self-Esteem and Quality of Life of the Elderly. International Journal of Gerontological Social welfare, 17, 157-189.

Koh, J. M., Jang, H. H., \& Ahn, S. K. (2012). The Effect of Proper Treatment on Abnormal Nail Conditions for the Female's Sentiment and Self Respect. Korean Journal of Aesthetics and Cosmetics Society, 10(1), 31-39.

Krause, N. (1987). Life stress, social support, and selfesteem in an elderly population. Psychology and Aging, 2(4), 349-56.

Lee, B. J., \& Hong, S. Y. (2012). The Effect of Older People's Leisure Activities on Their Self-Esteem and Life Satisfaction. Northeast Asia Tourism Research, 8(2), 139156.

Lee, S. H., Lee, K. O., \& Kim, S. O. (2009). Effects of Skin Care on Users' Mental Health and Self-esteem. Journal of The Korean Society of cosmetology, 15(1), 155-167.

Lemon, B. W., Bengtson, V. L., \& Petersan, J. A. (1992). "An Exploration of the Activity Theory of Aging: Activity Types and Life satisfaction among In-Movers to a Retirement Community. Journal of Gerontology, 35, 746757.

Maslow, A. (1970). Motivation and personality (2nd ed.). New York, NY: Harper \& Row.

Oh, E. J., Jung, J. Y., \& Choi, K. H. (2010). Effects of Melancholia and Self-respect to Old Females Receiving Beauty Services. Journal of The Korean Society of cosmetology, 16(2), 577-589.

Paik, J. E. (2008). Differences of Perceived Successful Aging According to Traditional Values for Korean Elderly. Korea Gerontological Society, 28(2), 227 249.

Rosenberg, M. (1965). Society and the adolescent selfimage. Princeton, NJ: Princeton University Press.

Rowe J. W. \& Kahn, R. L. (1998). Successful aging. New York, NY: Pantheon Books.

Song, K. Y. (2018). The Effects of Preparation for Aging of the Elderly on Successful Aging \& Mediating Effects of Life Satisfaction. International Journal of Gerontological Social welfare, 73(1), 469-503. 
Sung, H. Y., \& Cho, H. S. (2006). A Study of Successful Aging Model: Using the components of Rowe \& Kahn. Korea Gerontological Society, 26(1), 105 123.

Yi, E. S., \& Ahn, C. W. (2010). Effect of Leisure Sports Participation on the Successful Aging of Elderly: Analysis of the Intermediating Effect of Resilience. Korean journal of physical education, 49(4), 325-337. 